\title{
Panel Discussion: Social Media in Higher Education
}

\section{Daryl Nord and Jeretta Nord Oklahoma State University, Stillwater, OK, USA}

\author{
daryl.nord@okstate.edu; \\ jeretta.nord@okstate.edu
}

\author{
Alex Koohang \\ Macon State College, \\ Macon, GA, USA
}

alex.koohang@maconstate.edu

Material published as part of this publication, either on-line or in print, is copyrighted by the Informing Science Institute. Permission to make digital or paper copy of part or all of these works for personal or classroom use is granted without fee provided that the copies are not made or distributed for profit or commercial advantage AND that copies 1) bear this notice in full and 2) give the full citation on the first page. It is permissible to abstract these works so long as credit is given. To copy in all other cases or to republish or to post on a server or to redistribute to lists requires specific permission and payment of a fee. Contact Publisher@InformingScience.org to request redistribution permission. 
The purpose of this panel is to create a forum that explores the use of social media in higher education. Specifically the following themes will be discussed:

1. Social media's influence in higher education

2. Social media as a tool for learning

3. Current \& emerging issues in social media

The panelists will present one theme at a time. Participants will be invited to join the discussion.

\section{References}

Alexander, B. (2006). Web 2.0: A new wave of innovation for teaching and learning? Educause Review, $41(2), 32-44$.

Haung, D. C., \& Behara, R. S. (2007). Outcome-driven experimental learning with web 2.0. Journal of Information Systems Education, 18(3), 329 - 336.

Kaplan A., \& Haenlein M. (2010), Users of the world, unite! The challenges and opportunities of social media. Business Horizons, 53(1), 59-68.

O'Reilly, T. (2005). What is web 2.0. Retrieved March 6, 2010 from

http://www.oreillynet.com/pub/a/oreilly/tim/news/2005/09/30/what-is-web-20.html

\section{Biographies}

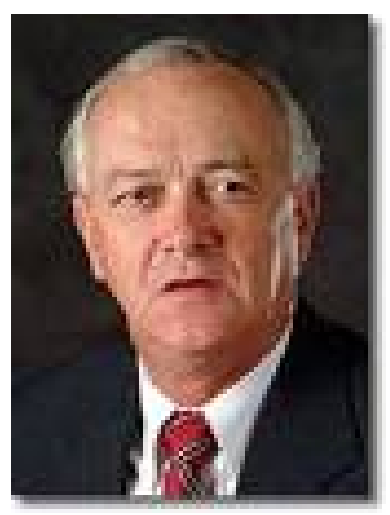

G. Daryl Nord is Professor of Management at Oklahoma State University. He is an active researcher and has published numerous articles and professional proceedings in areas including artificial intelligence/expert systems, systems analysis and design, the Internet, electronic commerce and others. He has served on national and international committees for professional organizations including Decision Sciences Institute, the Natural and Artificial Intelligence Systems Organization. Daryl serves as Managing Director to the IACIS Executive Board and Executive Editor of The Journal of Computer Information Systems.

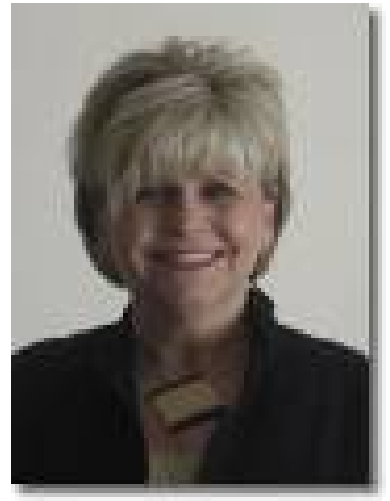

Jeretta Horn Nord is Professor of Management Information Systems at Oklahoma State University. She has recently served as Visiting Scholar at the University of California at Los Angeles and as a Visiting Professor at the University of Southern Queensland in Toowoomba, Australia; she has also been named Computer Educator of the Year by IACIS. She has authored numerous articles, proceedings and conference papers in the areas of e-business and corporate knowledge requirements. Jeretta serves as Director of Publications to the IACIS Executive Board and Executive Editor of The Journal of Computer Information Systems. 


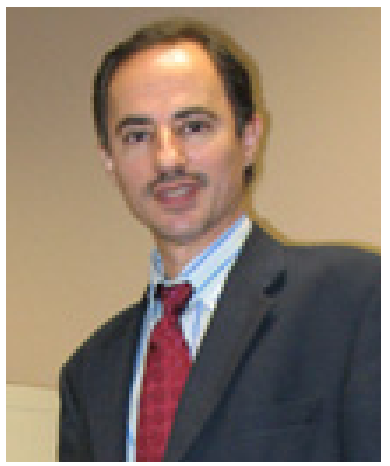

Alex Koohang is Peyton Anderson Eminent Scholar and Professor of Information Technology in the School of Information Technology at Macon State College. He is also the Dean of the School of Information Technology at Macon State College. Dr. Koohang has been involved in the development of online education, having initiated and administered some of the earliest asynchronous learning networks. His current research interests are in the areas of e-learning, learning objects, open education, and curriculum design. 